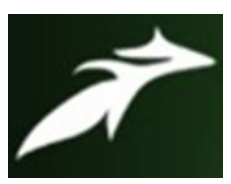

Ramakant Singh Sidar, International Journal of Advances in Agricultural Science and Technology,

Vol.2 Issue.11, November- 2015, pg. 64-76

ISSN: 2348-1358

\title{
Weed Management by Herbicide for Growth and Yield Attributing Characters in Mustard (Brassica juncea L. Czern \& Coss.)
}

\author{
Ramakant Singh Sidar \\ RMD College of Agriculture and Research Station, Indira Gandhi Krishi Vishwavidyalaya \\ Ambikapur, Surguja-497001 (Chhattisgargh) \\ DOI: 10.47856/ijaast.2015.v02i11.002
}

\begin{abstract}
A field experiment on Weed management by herbicide for growth and yield attributing characters in mustard was conducted on the RMD College of Agriculture \& Research Station, Ambikapur, during the Rabi season of 2012-2013. Soil of the experimental field was sandy loam in texture. 12 treatments with different herbicidal combination of weed management practices were study in randomized block design and 3 times replicated. weed control treatments Pendimethalin @ 1.0kg/ha PE, Glyphosate $50 \mathrm{gm} / \mathrm{ha}$ alone after emergence of Orobanche, Trifluralin @ 1.5kg/ha PPI, Glyphosate $25 \mathrm{gm} / \mathrm{ha}$ alone with $1 \%$ solution NH4SO 4 at 40 DAS, Neem cake at $200 \mathrm{~kg} / \mathrm{ha}$ in furrow and Pendimethalin at $0.5 \mathrm{~kg} / \mathrm{ha}$ (PE) followed by 1 hoeing at $40 \mathrm{DAS}$, Neem cake at $200 \mathrm{~kg} / \mathrm{ha}$ in furrow followed by Imazethapyr 30gm/ha at 20DAS, Trifluralin @ 1.5kg/ha +Neem oil 1\% PPI, soybean oil 2 drops / shoot after emergence of Orobanche, Application of $25 \%$ extra dose of phosphorus and phosphorus solubilizing bacteria, Trichoderma viride $2.5 \mathrm{~kg} / \mathrm{ha}$ as basal application, Farmers practice-1 hoeing at 40DAS and Weedy check, The study of revealed that the plant population was uniform under various weed control treatments. At 30 DAS and harvest, plant population varied from 10.99 to 12.55 and 10.10 to 11.55 per metre row length and Data pertaining to seed yield $\mathrm{kg} / \mathrm{ha}$ are presented in table 4.9 fig.4.9 appendix VIII It was clear from the data that application of pendimethalin (T1) produced significantly higher seed yield over all the weed control treatment except treatment $\mathrm{T} 7$ and T5. Data further revealed that the treatment T3 also gave significantly higher seed yield over rest the treatment except T1, T5, and T7.and the data on stover yield (kg/ha) presented in Table 4.9 and depicted through Fig.4.9. Further it clear from the data (table 4.9) that maximum stover yield $(\mathrm{kg} / \mathrm{ha})$ under $\mathrm{T} 1$ which was significantly higher over weedy check and T6 but at par with T7 and T5. Similarly treatment T3, T2, T4, T8, T9, T10 and T11 produced significantly higher stover yield over weedy check and T6 and they were statistically at par to each others.
\end{abstract}

Keywords: Mustard, Weed management, Herbicide Combinations 


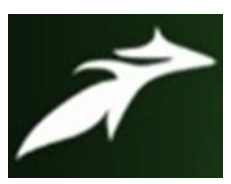

Ramakant Singh Sidar, International Journal of Advances in Agricultural Science and Technology,

Vol.2 Issue.11, November- 2015, pg. 64-76

ISSN: 2348-1358

\section{INTRODUCTION:}

Mustard (Brassica juncea I. Czern and Coss) is one of the most important oilseed crops grown in the world. It is grown both in subtropical and tropical countries. The maximum productivity of mustard depends upon the best utilization of available resources and improved technology. Oilseeds constitute the second largest agricultural commodity in Indian economy after cereal accounting for nearly $6 \%$ of gross national product and $10 \%$ of the value of all agricultural product, although India is one of the leading oilseeds producing countries in the world it is not able to meet the requirement of edible oil for its vast population. Mustard occupies place being next to groundnut both in area and production, providing the fat requirement of about $50 \%$ population in all the northern states of the country. Among the different oilseeds, mustard occupies an area of $6.18 \%$ million hectares with 7.36 million tonnes of total production and productivity of $1190 \mathrm{~kg} / \mathrm{ha}$ in India and in Chhattisgarh total area under mustard cultivation is 145.27 hectares with a production of $595 \mathrm{~kg} / \mathrm{hectares}$. Mustard is grown in winter season in India and about two third area under this crop is irrigated. The importance of any crop is judged by its yield potential, nutrient content, keeping quality and market value. The low production and productivity of mustard have been due to various constraints like inadequate and untimely use of fertilizer, unavailability and unsatisfactory irrigation facility at all the critical stages of crop growth, inadequate plant protection measures adopted by the farmers and poor handling of post harvest techniques including deficiency in marketing support, storage and processing. Among the production constraints, weed infestation causes considerable loss of yield ranging from 15$30 \%$. Critical period of crop weed competition is 15-40 days. Weeds compete with the crop plants for water, light, space and the required nutrients. The low productivity of mustard in the country might be the resultant of a number of factors viz. agronomic, edaphic, genetic and others. Among the agronomic factors, proper weed management may be a very serious issue (Singh 1992) Yield losses due to crop-weed competition in rapeseed-mustard have estimated to the tune of 10- 58\% (Bhan 1992, Banga and Yadav, 2001 and Singh et al. 2001) even ranging from 20-70 $\%$ depending upon the type of weed flora, magnitude and duration of weed infestation (Tiwari and Kurchania 1993) Competition by weeds at initial stages is a major limiting factor to its productivity. 


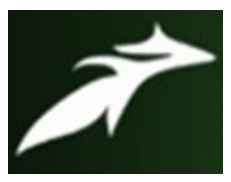

Ramakant Singh Sidar, International Journal of Advances in Agricultural Science and Technology, Vol.2 Issue.11, November- 2015, pg. 64-76

ISSN: 2348-1358

\section{MATERIALS AND METHODS:}

The field experiment was carried out during Rabi season of 2012-2013 at the Research farm, RMD College of Agriculture \& Research Station, Ambikapur situated at 23018' N latitude and 83015' Elongitude and at altitude of 611 meter above mean sea level which represents the northern hills agro-climatic zone of Chhattisgarh. The soil of the experimental site was sandy loam in texture, acidic in reaction ( $\mathrm{pH} 5.7)$, medium in organic carbon (0.56), available nitrogen (234 kg ha-1), available phosphorus (8.4 kg ha-1) and available potassium (268 kg ha-1). The experiment was carried out in randomized block design (RBD) with 3 replications. The treatments contained of nine weed management practices. The treatment comprised of Pendimethalin @ 1.0kg/ha PE, Glyphosate 50gm/ha alone after emergence of Orobanche, Trifluralin@ $1.5 \mathrm{~kg} / \mathrm{ha}$ PPI, Glyphosate 25gm/ha alone with $1 \%$ solution NH4SO4 at 40 DAS, Neem cake at $200 \mathrm{~kg} / \mathrm{ha}$ in furrow and Pendimethalin at $0.5 \mathrm{~kg} / \mathrm{ha}(\mathrm{PE})$ followed by 1 hoeing at 40 DAS, Neem cake at $200 \mathrm{~kg} /$ ha in furrow followed by Imazethapyr $30 \mathrm{gm} / \mathrm{ha}$ at $20 \mathrm{DAS}$, Trifluralin @ $1.5 \mathrm{~kg} / \mathrm{ha}+\mathrm{Neem}$ oil $1 \%$ PPI, soybean oil 2 drops / shoot after emergence of Orobanche, Application of $25 \%$ extra dose of phosphorus and phosphorus solubilizing bacteria, Trichoderma viride $2.5 \mathrm{~kg} / \mathrm{ha}$ as basal application, Farmers practice-1 hoeing at 40DAS and Weedy check. Data on weed population were recorded at 30, 60 days after sowing and at harvest. The observations of weed density and their dry matter were taken randomly from $0.25 \mathrm{~m} 2$ quadrate from net plot area from each treatment. To calculate the weed control Data on weed density and dry weight was subjected to square root transformation before analysis.

\section{RESULTS AND DISCUSSION:}

\section{Growth parameters}

\section{Plant population per metre row length}

The plant population was counted and recorded on the basis of per metre row length at 30 DAS and harvest stage. The data were subjected to statistical calculation. Where it was observed that the different weed control treatments did not affect the plant population significantly at 30 DAS as well as at harvest stage of crop. The study of Table-1 revealed that the plant population was uniform under various weed control treatments. At 30 DAS and harvest, plant population varied from 10.99 to 12.55 and 10.10 to 11.55 per metre row length, respectively. Similar results were reported by Singh et al. (2001), Kataria et al. (2003), Sharma et al. (2005). 


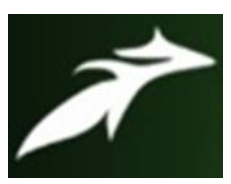

Ramakant Singh Sidar, International Journal of Advances in Agricultural Science and Technology, Vol.2 Issue.11, November- 2015, pg. 64-76

ISSN: 2348-1358

\section{Plant height (cm)}

The mean plant height at various stages of crop growth has been presented in Table-2 and illustrated in general, the plant height increased with the advancement in crop age, irrespective of the treatment and reached maximum at 90 DAS. The rate of increase in plant height was more during 30 to 60 DAS as compared to other growth periods. At 30DAS, all the treatments except T12, T8, T9, T10 and T11 produced significantly taller plant than T6. Among the treatments of weed control measures, tallest plant registered with treatment T5 closely followed in decreasing order by T7, T1, T2, T3, T4, T11 and T10. At 60DAS, all the treatments except T12, T8, T9, T10 and T11 produced significantly taller plant thanT6. Among the treatments of weed control measures, tallest plant registered with treatment $\mathrm{T} 1$ closely followed in decreasing order by T7, T5, T3, T4, T2, T11 and T10. At 90DAS and harvest, all the treatments except T12, T10, T8, T9, and T11 produced significantly taller plant thanT6. Among the treatments of weed control measures, tallest plant registered with treatment $\mathrm{T} 1$ closely followed in decreasing order by $\mathrm{T} 5$, T3, T7, T4, T2, T11 and T9. Singh et al. (2001), Kataria et al. (2003), Sharma et al. (2005) and Meena and Sah (2011) reported similar trend of results in mustard.

\section{Leaves per plant}

The number of leaves per plant was significantly influenced by the weed control measures at all the stages of crop growth (Table-3), there was a continuous increase in the number of leaves at all the stages of crop growth. Further, majority of leaves emerged out within 60 DAS and there was continuous increase in their number till 90 DAS in most of the treatments. All the leaves dropped at harvest stage. At 30DAS, all the treatments except produced significantly higher leaves/ plant thanT6. Among the treatments of weed control measures, highest number of leaves/plant registered with treatment $\mathrm{T} 1$ closely followed in decreasing order by T5, T7, T3, T9, T4, T2, T11, T10, T8 and T12. At 60DAS, all the treatments except produced significantly higher leaves/ plant thanT6. Among the treatments of weed control measures, highest number of leaves/plant registered with treatment $\mathrm{T} 1$ closely followed in decreasing order by T7, T5, T3, T4, T2, T11, T10, T9, T8 and T12. At 90DAS, all the treatments except produced significantly higher leaves/ plant thanT6. Among the treatments of weed control measures, highest number of leaves/plant registered with treatment $\mathrm{T} 1$ closely followed in decreasing order 


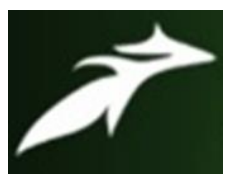

Ramakant Singh Sidar, International Journal of Advances in Agricultural Science and Technology, Vol.2 Issue.11, November- 2015, pg. 64-76

ISSN: 2348-1358

by T7, T5, T3, T11, T10, T4, T9, T2, T8 and T12. Singh et al. (2001), Kataria et al. (2003),

Sharma et al. (2005) and Meena and Sah (2011) reported similar trend of results in mustard.

\section{Branches per plant}

The analysis of variance (Appendix IV and V) exhibits that different weed control measures on number of branches per plant were statistically significant at all stages of observation. It can be observed from Table- 4 and 05 that the majority of branches emerged within 60 DAS while there was a slight increase in their number in later stages of crop growth. Similar results were reported by Singh et al. (2001), Kataria et al. (2003), Sharma et al. (2005)

\section{Primary branches}

At 60 DAS, the maximum number of branches per plant was recorded under T1 (2.93), which were statistically at par with T7, T5, T3, T4, T11, T2, T10 and T8. The minimum number of branches per plant was registered with T6 followed by T12 and T9. At 90 DAS and harvest, the entire treatments significantly higher primary branches per plant over T6. The maximum number of branches per plant was recorded in T1 (5.34) which were significantly higher than that other treatment except T7, T3 and T5. The minimum number of primary branches per plant was recorded in the treatment T6. Similar results were reported by Singh et al. (2001), Kataria et al. (2003), Sharma et al. (2005)

\section{Secondary branches}

At 60DAS, all the treatments except T6, T8, T9, T10, T2 and T11 produced significantly higher number of secondary branches than weedy check. Among the treatments of weed control measures, highest secondary branches registered with treatment $\mathrm{T} 1$ closely followed in decreasing order by T7, T5, T3 and T4. At 90DAS and harvest, all the treatments except T6, T8, T9, T10, and T11 produced significantly higher number of secondary branches than weedy check. Among the treatments of weed control measures, highest secondary branches registered with treatment T1 closely followed in decreasing order by T7, T5, T3, T4 and T2. Similar results were reported by Singh et al. (2001), Kataria et al. (2003), Sharma et al. (2005)

\section{Dry weight per plant}

The data recorded in respect of dry weight per plant were analysed statistically. The mean dry weight per plant is presented in Table-6. At 30DAS, all the treatments except T6, T8, T9, T10, T2, T11 and T4 produced significantly higher dry weight than weedy check. Among the 


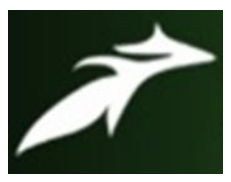

Ramakant Singh Sidar, International Journal of Advances in Agricultural Science and Technology, Vol.2 Issue.11, November- 2015, pg. 64-76

treatments of weed control measures, highest dry weight registered with treatment $\mathrm{T} 1$ closely followed in decreasing order by $\mathrm{T} 7, \mathrm{~T} 5$ and $\mathrm{T} 3$.

At 60DAS, all the treatments except $\mathrm{T} 12, \mathrm{~T} 8, \mathrm{~T} 9, \mathrm{~T} 10$ andT11 produced significantly higher dry weight than T6. Among the treatments of weed control measures, highest dry weight registered with treatment $\mathrm{T} 1$ closely followed in decreasing order by T7, T5, T3, T4 and T2. At 90DAS, all the treatments except T12 produced significantly higher dry weight than T6. Among the treatments of weed control measures, highest dry weight registered with treatment T1 closely followed in decreasing order by T7, T5, T3, T4, T2, T9, T11, T10 and T8. At harvest, all the treatments except T6 produced significantly higher dry weight than weedy check. Among the treatments of weed control measures, highest dry weight registered with treatment T1 closely followed in decreasing order by T7, T5, T3, T4, T2, T9, T11, T10.

\section{Yield attributing characters}

\section{Number of siliquae per plant}

Analysis of variance indicated that weed control treatment exerted significant influence on this yield attributing character. It is obvious from the data (Table-7) that number of siliquae per plant showed a positive response to most of the weed control measures. Among all the weed control treatments, $\mathrm{T} 1$ recorded significantly higher number of siliquae per plant, but it was at par with T7 and both are significantly over rest of the treatments. Minimum number of siliquae per plant (171.06) was registered with weedy check which was at par with T6.The treatments T8, T9, T10 and T11 also recorded statistically similar siliquae per plant and significantly higher siliquae per plant over weedy check and T6. Similar results were reported by Singh et al. (2001), Kataria et al. (2003), Sharma et al. (2005).

\section{Length of siliqua (cm)}

The analysis of variance on length of siliqua at harvest is given in Appendix VII where it was observed that effect of treatments on length of siliquae was significant. The highest length of siliquae $(3.95 \mathrm{~cm}$ ) was recorded in $\mathrm{T} 1$ treatment, which was at par with $\mathrm{T} 7, \mathrm{~T} 5$ and $\mathrm{T} 3$ treatment and significantly superior over rest of the treatments including weedy check. The minimum length of siliqua $(2.99 \mathrm{~cm}$ ) was recorded in T6 followed by T8, T9, T10, and T11 treatments (Table-5). 


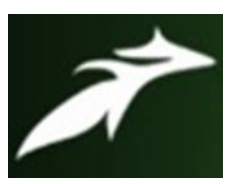

Ramakant Singh Sidar, International Journal of Advances in Agricultural Science and Technology, Vol.2 Issue.11, November- 2015, pg. 64-76

ISSN: 2348-1358

\section{Seeds/siliqua}

Weed management practices improved the number of seeds per siliquae of mustard (Table-5). Highest numbers of seeds per siliquae was recorded under T1 which was at par with T7, T5 and T3.They are significantly superior over weedy check \& T6. Treatments T2, T4, T8, T9, T10 and T11 are not reached to the levels of significant but they are statistically at par to each other and significantly superior over T6.

\section{Seed weight (g/plant)}

All the weed control treatment recorded significantly higher in seed weight per plant as compared to weedy check and T9 (Table-8).Treatment T1 gave significantly higher seed weight per plant over weedy check and T9 and at par with T7 \& T5. Similarly treatment T2, T3, T4, T6, T8, T10 and T11 were also statistically at par in respect of seed weight per plant. They were also superior to weedy check and T9.

\section{0 seed weight $(\mathrm{g})$}

All the weed control treatments produced significantly higher 1000 seed weight over weedy check except T6 and T9. Application of pendimethalin registered significantly higher 1000 seed weight over weedy check, T6 \& T9 but at par with T7, T5 and T3. Remaining treatments were also at par. Similresults were reported by Singh et al. (2001), Kataria et al. (2003), Sharma et al. (2005).

\section{References}

[1]. Banga R.S. and Yadav, A. (2001). Evaluation of herbicides against complex weed flora in Indian mustard. Haryana Journal of Agronomy : 17:48-51.

[2]. Bhan V.M. (1992). Weed management a factor for sustainability in crop production In: Proceeding of XII National Symposium on Resource Management for Sustained Crop Production, held At Rajasthan Agriculture University, Bikaner, 209-2016.

[3]. Kataria, O.P., Chauhan, D.R. and Balyan, R.S. (2003). Effect of herbicides on weeds and seed yield of tobacco (Nicotiana tobacum L.). Indian J. Weed Sci. 35 (1/2): 151-152.

[4]. Meena, M. L. and Dinesh Sah (2011). Effect of weed control and fertilization on yield attributes and seed yield of mustard (Brassic juncea L.) under western plains of UP. Environment and Ecology;. 29: (2A), 929-931. 5.

[5]. Sharma, S.K., Singh, Vireshwar and Panwar, K.S. (2005). Weed management in Indian mustard (Brassica juncea) under dryland conditions. Indian J Agric. Sci. 75 (5): 288-289. 


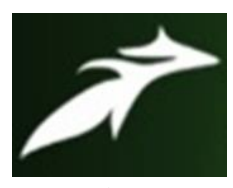

Ramakant Singh Sidar, International Journal of Advances in Agricultural Science and Technology,

Vol.2 Issue.11, November- 2015, pg. 64-76

ISSN: 2348-1358

[6]. Singh SS. (1992). Effect of fertilizer application and weed control on the yield of mustard (Brassica juncea). Indian Journal of Agronomy.; 37:196-198.

[7]. Singh.; Harphool., Singh, B.P. and Prasad, Hanuman. (2001). Weed management in Brassica species. Indian J. Agron. 46 (3): 533-537.

[8]. Tiwari J.P. and Kurchania, S.P. (1993). Chemical control of weeds in Indian mustard (Brassica juncea L.). Indian Agricultural Sciences; 63:272-275.

Table.-1. Plant population of mustard at 30 DAS and harvest as influenced by different weed control measures

\begin{tabular}{|c|c|c|c|}
\hline \multirow[t]{2}{*}{ S. No. } & \multirow[t]{2}{*}{ Treatment } & \multicolumn{2}{|c|}{$\begin{array}{l}\text { Plant population per } \\
\text { metre row length at }\end{array}$} \\
\hline & & 30 DAS & Harvest \\
\hline 1 & $\mathrm{~T}_{1}$ - Pendimethalin @ 1.0kg/ha PE & 11.22 & 10.46 \\
\hline 2 & $\begin{array}{l}\mathrm{T}_{2-} \text { Glyphosate } 50 \mathrm{gm} / \text { ha alone after emergence of } \\
\text { Orobanche }\end{array}$ & 12.22 & 11.10 \\
\hline 3 & $\mathrm{~T}_{3}$ - Trifluralin @ 1.5kg/ha PPI & 11.55 & 10.55 \\
\hline 4 & $\begin{array}{l}\mathrm{T}_{4} \text { - Glyphosate } 25 \mathrm{gm} / \mathrm{ha} \text { alone with } 1 \% \text { solution } \mathrm{NH} 4 \mathrm{SO} 4 \\
\text { at } 40 \mathrm{DAS}\end{array}$ & 12.22 & 11.44 \\
\hline 5 & $\begin{array}{l}\mathrm{T}_{5}-\text { Neem cake at } 200 \mathrm{~kg} / \mathrm{ha} \text { in furrow and Pendimethalin at } \\
0.5 \mathrm{~kg} / \mathrm{ha}(\mathrm{PE}) \text { followed by } 1 \text { hoeing at } 40 \mathrm{DAS}\end{array}$ & 11.99 & 11.00 \\
\hline 6 & $\begin{array}{l}\mathrm{T}_{6} \text { - Neem cake at } 200 \mathrm{~kg} / \mathrm{ha} \text { in furrow followed by } \\
\text { Imazethapyr } 30 \mathrm{gm} / \mathrm{ha} \text { at } 20 \mathrm{DAS}\end{array}$ & 12.44 & 10.11 \\
\hline 7 & $\mathrm{~T}_{7-}$ Trifluralin@ $@ 1.5 \mathrm{~kg} / \mathrm{ha}+\mathrm{Neem}$ oil 1\% PPI & 12.44 & 11.55 \\
\hline 8 & $\begin{array}{l}\mathrm{T}_{8} \text { - Soybean oil } 2 \text { drops / shoot after emergence of } \\
\text { Orobanche }\end{array}$ & 12.00 & 11.44 \\
\hline 9 & $\begin{array}{l}\mathrm{T}_{9-} \text { Application of } 25 \% \text { extra dose of phosphorus and } \\
\text { phosphorus solubilizing bacteria }\end{array}$ & 12.44 & 11.55 \\
\hline 10 & $\mathrm{~T}_{10^{-}}$Trichoderma viride $2.5 \mathrm{~kg} / \mathrm{ha}$ as basal application & 12.55 & 11.22 \\
\hline 11 & $\mathrm{~T}_{11}$ - Farmers practice-1 hoeing at 40DAS & 12.22 & 11.55 \\
\hline 12 & $\mathrm{~T}_{12}-$ Weedy check & 10.99 & 10.10. \\
\hline & S.E.m \pm & 0.543 & 0.516 \\
\hline & C.D. at $5 \%$ & NS & NS \\
\hline
\end{tabular}

Table-2. Plant height of mustard at successive crop growth stages as influenced by different weed control measures

\begin{tabular}{|c|c|c|c|c|c|}
\hline \multirow[t]{2}{*}{ S. No. } & \multirow[t]{2}{*}{ Treatment } & \multicolumn{4}{|c|}{ Plant height (cm) } \\
\hline & & $\begin{array}{l}30 \\
\text { DAS }\end{array}$ & $\begin{array}{l}60 \\
\text { DAS }\end{array}$ & $\begin{array}{l}90 \\
\text { DAS }\end{array}$ & Harvest \\
\hline 1 & $\mathrm{~T}_{1}$ - Pendimethalin @ 1.0kg/ha PE & 15.46 & 69.86 & 190.06 & 190.09 \\
\hline 2 & $\begin{array}{l}\mathrm{T}_{2} \text { - Glyphosate } 50 \mathrm{gm} / \text { ha alone after emergence of } \\
\text { Orobanche }\end{array}$ & 15.13 & 64.60 & 182.53 & 182.53 \\
\hline 3 & $\mathrm{~T}_{3}$ - Trifluralin @ 1.5kg/ha PPI & 15.06 & 67.33 & 185.80 & 185.80 \\
\hline
\end{tabular}




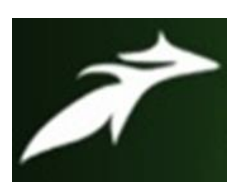

Ramakant Singh Sidar, International Journal of Advances in Agricultural Science and Technology,

Vol.2 Issue.11, November- 2015, pg. 64-76

ISSN: 2348-1358

\begin{tabular}{|c|c|c|c|c|c|}
\hline 4 & $\begin{array}{l}\mathrm{T}_{4^{-}} \text {Glyphosate } 25 \mathrm{gm} / \text { ha alone with } 1 \% \text { solution } \\
\mathrm{NH} 4 \mathrm{SO} 4 \text { at } 40 \text { DAS }\end{array}$ & 15.00 & 65.33 & 183.00 & 183.00 \\
\hline 5 & $\begin{array}{l}\mathrm{T}_{5} \text { - Neem cake at } 200 \mathrm{~kg} / \mathrm{ha} \text { in furrow and } \\
\text { Pendimethalin at } 0.5 \mathrm{~kg} / \mathrm{ha}(\mathrm{PE}) \text { followed by } 1 \\
\text { hoeing at } 40 \text { DAS }\end{array}$ & 15.80 & 68.80 & 187.86 & 187.86 \\
\hline 6 & $\begin{array}{l}\mathrm{T}_{6} \text { - Neem cake at } 200 \mathrm{~kg} / \mathrm{ha} \text { in furrow followed by } \\
\text { Imazethapyr } 30 \mathrm{gm} / \mathrm{ha} \text { at } 20 \mathrm{DAS}\end{array}$ & 12.93 & 56.23 & 171.00 & 171.00 \\
\hline 7 & $\mathrm{~T}_{7-}$ Trifluralin@1.5kg/ha +Neem oil 1\% PPI & 15.60 & 69.66 & 185.66 & 185.66 \\
\hline 8 & $\begin{array}{l}\mathrm{T}_{8} \text { - Soybean oil } 2 \text { drops / shoot after emergence of } \\
\text { Orobanche }\end{array}$ & 13.26 & 58.03 & 178.00 & 178.00 \\
\hline 9 & $\begin{array}{l}\mathrm{T}_{9-} \text { Application of } 25 \% \text { extra dose of phosphorus } \\
\text { and phosphorus solubilizing bacteria }\end{array}$ & 13.73 & 59.06 & 178.10 & 178.10 \\
\hline 10 & $\begin{array}{l}\mathrm{T}_{10^{-}} \text {Trichoderma viride } 2.5 \mathrm{~kg} / \mathrm{ha} \text { as basal } \\
\text { application }\end{array}$ & 14.00 & 62.13 & 174.33 & 174.33 \\
\hline 11 & $\mathrm{~T}_{11}$ - Farmers practice- 1 hoeing at 40DAS & 14.06 & 63.23 & 178.13 & 178.13 \\
\hline \multirow[t]{3}{*}{12} & $\mathrm{~T}_{12-}$ Weedy check & 12.96 & 63.33 & 172.73 & 172.73 \\
\hline & S.E.m \pm & 0.689 & 2.516 & 2.465 & 2.465 \\
\hline & C.D. at 5\% & 2.021 & 7.379 & 7.232 & 7.232 \\
\hline
\end{tabular}

Table-3. Number of leaves of mustard at successive crop growth stages as influenced by different weed control measures

\begin{tabular}{|c|c|c|c|c|}
\hline \multirow[t]{2}{*}{ S. No. } & \multirow[t]{2}{*}{ Treatment } & \multicolumn{3}{|c|}{ Leaves/plant } \\
\hline & & $30 \mathrm{DAS}$ & 60 DAS & Harvest \\
\hline 1 & $\mathrm{~T}_{1}$ - Pendimethalin@1.0kg/ha PE & 5.26 & 22.00 & 49.86 \\
\hline 2 & $\begin{array}{l}T_{2} \text { - Glyphosate } 50 \mathrm{gm} / \mathrm{ha} \text { alone after emergence of } \\
\text { Orobanche }\end{array}$ & 4.73 & 18.40 & 43.13 \\
\hline 3 & $\mathrm{~T}_{3^{-}}$Trifluralin @ 1.5kg/ha PPI & 5.00 & 19.43 & 48.40 \\
\hline 4 & $\begin{array}{l}\mathrm{T}_{4-} \text { - Glyphosate } 25 \mathrm{gm} / \mathrm{ha} \text { alone with } 1 \% \text { solution } \\
\mathrm{NH} 4 \mathrm{SO} 4 \text { at } 40 \mathrm{DAS}\end{array}$ & 4.80 & 18.46 & 44.40 \\
\hline 5 & $\begin{array}{l}\mathrm{T}_{5^{-}} \text {Neem cake at } 200 \mathrm{~kg} / \mathrm{ha} \text { in furrow and } \\
\text { Pendimethalin at } 0.5 \mathrm{~kg} / \mathrm{ha}(\mathrm{PE}) \text { followed by } 1 \text { hoeing } \\
\text { at } 40 \text { DAS }\end{array}$ & 5.06 & 19.46 & 48.80 \\
\hline 6 & $\begin{array}{l}\mathrm{T}_{6}-\text { Neem cake at } 200 \mathrm{~kg} / \mathrm{ha} \text { in furrow followed by } \\
\text { Imazethapyr } 30 \mathrm{gm} / \mathrm{ha} \text { at } 20 \mathrm{DAS}\end{array}$ & 3.30 & 13.26 & 32.93 \\
\hline 7 & $\mathrm{~T}_{7-}$ Trifluralin@1.5kg/ha +Neem oil 1\% PPI & 5.06 & 20.86 & 49.53 \\
\hline 8 & $\begin{array}{l}\mathrm{T}_{8} \text { - Soybean oil } 2 \text { drops / shoot after emergence of } \\
\text { Orobanche }\end{array}$ & 4.46 & 17.26 & 39.20 \\
\hline 9 & $\begin{array}{l}\mathrm{T}_{9^{-}} \text {Application of } 25 \% \text { extra dose of phosphorus } \\
\text { and phosphorus solubilizing bacteria }\end{array}$ & 4.93 & 17.60 & 43.73 \\
\hline 10 & $\begin{array}{l}\mathrm{T}_{10^{-}} \text {Trichoderma viride } 2.5 \mathrm{~kg} / \mathrm{ha} \text { as basal } \\
\text { application }\end{array}$ & 4.66 & 18.00 & 44.53 \\
\hline 11 & $\mathrm{~T}_{11}$ - Farmers practice-1 hoeing at 40DAS & 4.73 & 18.20 & 46.00 \\
\hline
\end{tabular}




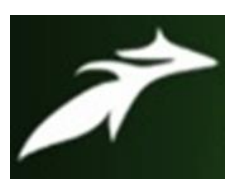

Ramakant Singh Sidar, International Journal of Advances in Agricultural Science and Technology,

Vol.2 Issue.11, November- 2015, pg. 64-76

ISSN: 2348-1358

\begin{tabular}{|c|c|c|c|c|}
\hline 12 & $\mathrm{~T}_{12}-$ Weedy check & 4.23 & 16.36 & 38.56 \\
\hline & S.E.m \pm & 0.252 & 1.037 & 1.899 \\
\hline & C.D. at 5\% & 0.740 & 3.042 & 5.571 \\
\hline
\end{tabular}

Table-4. Primary branches per plant of mustard at successive crop growth stages as influenced by different weed control measures

\begin{tabular}{|c|c|c|c|c|}
\hline \multirow[t]{2}{*}{ S. No. } & \multirow[t]{2}{*}{ Treatment } & \multicolumn{3}{|c|}{ Primary branches /plant } \\
\hline & & 60 DAS & $90 \mathrm{DAS}$ & Harvest \\
\hline 1 & $\mathrm{~T}_{1}$ - Pendimethalin @ 1.0kg/ha PE & 2.93 & 5.34 & 5.34 \\
\hline 2 & $\begin{array}{l}\mathrm{T}_{2-} \text { Glyphosate } 50 \mathrm{gm} / \mathrm{ha} \text { alone after emergence of } \\
\text { Orobanche }\end{array}$ & 2.46 & 4.70 & 4.70 \\
\hline 3 & $\mathrm{~T}_{3}$ - Trifluralin @ 1.5kg/ha PPI & 2.80 & 5.24 & 5.24 \\
\hline 4 & $\begin{array}{l}\mathrm{T}_{4} \text { - Glyphosate } 25 \mathrm{gm} / \mathrm{ha} \text { alone with } 1 \% \text { solution } \\
\mathrm{NH} 4 \mathrm{SO} 4 \text { at } 40 \mathrm{DAS}\end{array}$ & 2.53 & 4.89 & 4.89 \\
\hline 5 & $\begin{array}{l}\mathrm{T}_{5} \text { - Neem cake at } 200 \mathrm{~kg} / \mathrm{ha} \text { in furrow and } \\
\text { Pendimethalin at } 0.5 \mathrm{~kg} / \mathrm{ha}(\mathrm{PE}) \text { followed by } 1 \text { hoeing } \\
\text { at } 40 \text { DAS }\end{array}$ & 2.83 & 5.13 & 5.13 \\
\hline 6 & $\begin{array}{l}\mathrm{T}_{6} \text { - Neem cake at } 200 \mathrm{~kg} / \mathrm{ha} \text { in furrow followed by } \\
\text { Imazethapyr } 30 \mathrm{gm} / \mathrm{ha} \text { at } 20 \mathrm{DAS}\end{array}$ & 1.66 & 3.46 & 3.46 \\
\hline 7 & $\mathrm{~T}_{7^{-}}$Trifluralin@1.5kg/ha +Neem oil 1\% PPI & 2.90 & 5.33 & 5.33 \\
\hline 8 & $\begin{array}{l}\mathrm{T}_{8}-\text { Soybean oil } 2 \text { drops / shoot after emergence of } \\
\text { Orobanche }\end{array}$ & 2.33 & 4.56 & 4.56 \\
\hline 9 & $\begin{array}{l}\mathrm{T}_{9^{-}} \text {Application of } 25 \% \text { extra dose of phosphorus } \\
\text { and phosphorus solubilizing bacteria }\end{array}$ & 2.23 & 463 & 4.63 \\
\hline 10 & $\begin{array}{l}\mathrm{T}_{10} \text { - Trichoderma viride } 2.5 \mathrm{~kg} / \mathrm{ha} \text { as basal } \\
\text { application }\end{array}$ & 2.40 & 4.56 & 4.56 \\
\hline 11 & $\mathrm{~T}_{11}$ - Farmers practice-1 hoeing at 40DAS & 2.50 & 4.70 & 4.70 \\
\hline 12 & $\mathrm{~T}_{12}-$ Weedy check & 2.20 & 4.13 & 4.13 \\
\hline & S.E.m \pm & 0.207 & 0.148 & 0.148 \\
\hline & C.D. at $5 \%$ & 0.609 & 0.435 & 0.435 \\
\hline
\end{tabular}

Table-5. Secondary branches per plant of mustard at successive crop growth stages as influenced by different weed control measures

\begin{tabular}{|l|l|l|l|l|}
\hline S. No. & Treatment & \multicolumn{3}{|l|}{ Secondary branches /plant } \\
\cline { 3 - 5 } & & 60 DAS & 90 DAS & Harvest \\
\hline 1 & $T_{1}$ - Pendimethalin @ 1.0kg/ha PE & 6.93 & 8.73 & 8.73 \\
\hline 2 & $\begin{array}{l}T_{2} \text {-Glyphosate 50gm/ha alone after emergence of } \\
\text { Orobanche }\end{array}$ & 6.06 & 7.86 & 7.86 \\
\hline 3 & $T_{3}$ Trifluralin @ 1.5kg/ha PPI & 6.63 & 8.36 & 8.36 \\
\hline 4 & $\begin{array}{l}\mathrm{T}_{4} \text { - Glyphosate } 25 \mathrm{gm} / \mathrm{ha} \text { alone with 1\% solution } \\
\text { NH4SO4 at 40 DAS }\end{array}$ & 6.33 & 8.03 & 8.03 \\
\hline
\end{tabular}




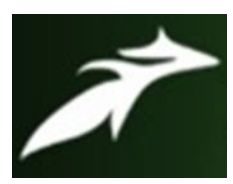

Ramakant Singh Sidar, International Journal of Advances in Agricultural Science and Technology,

Vol.2 Issue.11, November- 2015, pg. 64-76

ISSN: 2348-1358

\begin{tabular}{|c|c|c|c|c|}
\hline 5 & $\begin{array}{l}\mathrm{T}_{5} \text { - Neem cake at } 200 \mathrm{~kg} / \mathrm{ha} \text { in furrow and } \\
\text { Pendimethalin at } 0.5 \mathrm{~kg} / \mathrm{ha}(\mathrm{PE}) \text { followed by } 1 \text { hoeing } \\
\text { at } 40 \mathrm{DAS}\end{array}$ & 6.70 & 8.56 & 8.56 \\
\hline 6 & $\begin{array}{l}\mathrm{T}_{6} \text { - Neem cake at } 200 \mathrm{~kg} / \mathrm{ha} \text { in furrow followed by } \\
\text { Imazethapyr } 30 \mathrm{gm} / \mathrm{ha} \text { at } 20 \mathrm{DAS}\end{array}$ & 5.53 & 6.51 & 6.51 \\
\hline 7 & $\mathrm{~T}_{7-}$ Trifluralin @ 1.5kg/ha +Neem oil 1\% PPI & 6.86 & 8.66 & 8.66 \\
\hline 8 & $\begin{array}{l}T_{8} \text { - Soybean oil } 2 \text { drops / shoot after emergence of } \\
\text { Orobanche }\end{array}$ & 5.73 & 6.86 & 6.86 \\
\hline 9 & $\begin{array}{l}\mathrm{T}_{9^{-}} \text {Application of } 25 \% \text { extra dose of phosphorus } \\
\text { and phosphorus solubilizing bacteria }\end{array}$ & 5.80 & 6.86 & 6.86 \\
\hline 10 & $\begin{array}{l}\mathrm{T}_{10^{-}} \text {Trichoderma viride } 2.5 \mathrm{~kg} / \mathrm{ha} \text { as basal } \\
\text { application }\end{array}$ & 5.83 & 7.20 & 7.20 \\
\hline 11 & $\mathrm{~T}_{11}$ - Farmers practice- 1 hoeing at 40DAS & 6.13 & 7.26 & 7.26 \\
\hline \multirow[t]{3}{*}{12} & $\mathrm{~T}_{12-}$ Weedy check & 5.40 & 6.50 & 6.50 \\
\hline & S.E.m \pm & 0.294 & 0.176 & 0.276 \\
\hline & C.D. at $5 \%$ & $\mathbf{0 . 8 6 3}$ & 0.809 & 0.809 \\
\hline
\end{tabular}

Table-6. Dry weight per plant of crop growth stages as influenced different weed control measures

\begin{tabular}{|c|c|c|c|c|c|}
\hline \multirow[t]{2}{*}{ S. No. } & \multirow[t]{2}{*}{ Treatment } & \multicolumn{4}{|c|}{ Dry weight per plant (in gm) } \\
\hline & & $\begin{array}{l}30 \\
\text { DAS }\end{array}$ & $\begin{array}{l}60 \\
\text { DAS }\end{array}$ & $\begin{array}{l}90 \\
\text { DAS }\end{array}$ & Harvest \\
\hline & & 1.50 & 17.63 & 51.86 & 69.86 \\
\hline 1 & $\mathrm{~T}_{1}$ - Pendimethalin@1.0kg/ha PE & & & & \\
\hline 2 & $\begin{array}{l}\mathrm{T}_{2^{-}} \text {Glyphosate } 50 \mathrm{gm} / \text { ha alone after emergence of } \\
\text { Orobanche }\end{array}$ & 1.30 & 16.13 & 40.06 & 57.26 \\
\hline 3 & $\mathrm{~T}_{3^{-}}$Trifluralin @ 1.5kg/ha PPI & 1.40 & 16.83 & 45.56 & 62.13 \\
\hline 4 & $\begin{array}{l}\mathrm{T}_{4-} \text { Glyphosate } 25 \mathrm{gm} / \mathrm{ha} \text { alone with } 1 \% \text { solution } \\
\text { NH4SO4 at } 40 \text { DAS }\end{array}$ & 1.36 & 16.66 & 42.23 & 58.80 \\
\hline 5 & $\begin{array}{l}\mathrm{T}_{5^{-}} \text {Neem cake at } 200 \mathrm{~kg} / \mathrm{ha} \text { in furrow and } \\
\text { Pendimethalin at } 0.5 \mathrm{~kg} / \mathrm{ha}(\mathrm{PE}) \text { followed by } 1 \text { hoeing } \\
\text { at } 40 \text { DAS }\end{array}$ & 1.43 & 16.90 & 48.60 & 66.10 \\
\hline 6 & $\begin{array}{l}\mathrm{T}_{6} \text { - Neem cake at } 200 \mathrm{~kg} / \mathrm{ha} \text { in furrow followed by } \\
\text { Imazethapyr } 30 \mathrm{gm} / \mathrm{ha} \text { at } 20 \mathrm{DAS}\end{array}$ & 1.20 & 14.23 & 33.76 & 44.80 \\
\hline 7 & $\mathrm{~T}_{7-}$ Trifluralin @ 1.5kg/ha +Neem oil 1\% PPI & 1.46 & 16.90 & 49.43 & 67.20 \\
\hline 8 & $\begin{array}{l}\mathrm{T}_{8} \text { - Soybean oil } 2 \text { drops / shoot after emergence of } \\
\text { Orobanche }\end{array}$ & 1.20 & 14.56 & 35.63 & 51.73 \\
\hline 9 & $\begin{array}{l}\mathrm{T}_{9^{-}} \text {Application of } 25 \% \text { extra dose of phosphorus } \\
\text { and phosphorus solubilizing bacteria }\end{array}$ & 1.26 & 14.96 & 39.16 & 52.43 \\
\hline 10 & $\begin{array}{l}\mathrm{T}_{10^{-}} \text {Trichoderma viride } 2.5 \mathrm{~kg} / \mathrm{ha} \text { as basal } \\
\text { application }\end{array}$ & 1.30 & 15.33 & 37.03 & 53.43 \\
\hline 11 & $\mathrm{~T}_{11}$ - Farmers practice- 1 hoeing at 40DAS & 1.30 & 16.66 & 38.03 & 54.86 \\
\hline
\end{tabular}




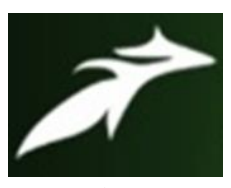

Ramakant Singh Sidar, International Journal of Advances in Agricultural Science and Technology,

Vol.2 Issue.11, November- 2015, pg. 64-76

ISSN: 2348-1358

\begin{tabular}{|l|lr|l|l|l|l|}
\hline 12 & $\mathrm{~T}_{12}$ - Weedy check & 1.06 & 14.26 & 34.66 & 43.63 \\
\cline { 2 - 7 } & & S.E.m \pm & $\mathbf{0 . 1 1}$ & $\mathbf{0 . 5 7}$ & $\mathbf{0 . 4 9}$ & $\mathbf{0 . 6 9}$ \\
\hline & C.D. at 5\% & $\mathbf{0 . 3 2}$ & $\mathbf{1 . 6 7}$ & $\mathbf{1 . 4 5}$ & $\mathbf{2 . 0 3}$ \\
\hline
\end{tabular}

Table-7. Number of siliquae per plant, length of siliqua and number of seeds per siliqua of mustard as influenced by different weed control measures

\begin{tabular}{|c|c|c|c|c|}
\hline S. No. & Treatment & $\begin{array}{l}\text { Siliquae/ } \\
\text { plant }\end{array}$ & $\begin{array}{l}\text { Length } \\
\text { of siliqua } \\
\text { (cm) }\end{array}$ & $\begin{array}{l}\text { Seeds/ } \\
\text { siliqua }\end{array}$ \\
\hline & & 277.53 & 3.95 & 15.16 \\
\hline 2 & $\begin{array}{l}\mathrm{T}_{2} \text { - Glyphosate } 50 \mathrm{gm} / \mathrm{ha} \text { alone after emergence of } \\
\text { Orobanche }\end{array}$ & 217.23 & 3.68 & 12.93 \\
\hline 3 & $\mathrm{~T}_{3}$ - Trifluralin@1.5kg/ha PPI & 240.50 & 3.84 & 13.83 \\
\hline 4 & $\begin{array}{l}\mathrm{T}_{4} \text { - Glyphosate } 25 \mathrm{gm} / \mathrm{ha} \text { alone with } 1 \% \text { solution } \\
\mathrm{NH} 4 \mathrm{SO} 4 \text { at } 40 \mathrm{DAS}\end{array}$ & 229.70 & 3.75 & 13.16 \\
\hline 5 & $\begin{array}{l}T_{5} \text { - Neem cake at } 200 \mathrm{~kg} / \mathrm{ha} \text { in furrow and } \\
\text { Pendimethalin at } 0.5 \mathrm{~kg} / \mathrm{ha} \text { (PE) followed by } 1 \text { hoeing } \\
\text { at } 40 \text { DAS }\end{array}$ & 246.76 & 3.86 & 13.90 \\
\hline 6 & $\begin{array}{l}\mathrm{T}_{6} \text { - Neem cake at } 200 \mathrm{~kg} / \mathrm{ha} \text { in furrow followed by } \\
\text { Imazethapyr } 30 \mathrm{gm} / \mathrm{ha} \text { at } 20 \mathrm{DAS}\end{array}$ & 180.66 & 2.99 & 10.73 \\
\hline 7 & $\mathrm{~T}_{7}$ - Trifluralin@ $1.5 \mathrm{~kg} / \mathrm{ha}+$ Neem oil 1\% PPI & 252.86 & 3.87 & 14.70 \\
\hline 8 & $\begin{array}{l}\mathrm{T}_{8-} \text { Soybean oil } 2 \text { drops / shoot after emergence of } \\
\text { Orobanche }\end{array}$ & 195.73 & 3.58 & 12.76 \\
\hline 9 & $\begin{array}{l}\mathrm{T}_{9-} \text { Application of } 25 \% \text { extra dose of phosphorus } \\
\text { and phosphorus solubilizing bacteria }\end{array}$ & 190.86 & 3.56 & 12.73 \\
\hline 10 & $\begin{array}{l}\mathrm{T}_{10-} \text { - Trichoderma viride } 2.5 \mathrm{~kg} / \mathrm{ha} \text { as basal } \\
\text { application }\end{array}$ & 201.13 & 3.58 & 12.90 \\
\hline 11 & $T_{11^{-}}$Farmers practice- 1 hoeing at 40DAS & 207.86 & 3.61 & 12.90 \\
\hline \multirow[t]{3}{*}{12} & $\mathrm{~T}_{12^{-}}$Weedy check & 171.06 & 3.46 & 12.10 \\
\hline & S.E.m \pm & 2.249 & 0.057 & 0.56 \\
\hline & C.D. at 5\% & 6.597 & 0.170 & 1.66 \\
\hline
\end{tabular}

Table-8. Seed and 1000 seed weight of mustard as influenced by different weed control measures

\begin{tabular}{|l|l|l|l|}
\hline S. No. & Treatment & $\begin{array}{l}\text { Seed } \\
\text { weight/pl } \\
\text { ant }(\mathbf{g})\end{array}$ & $\begin{array}{l}\mathbf{1 0 0 0} \text { Seed } \\
\text { weight } \\
\text { (g) }\end{array}$ \\
\hline 1 & $\begin{array}{l}\text { T1- Pendimethalin @ 1.0kg/ha PE } \\
19.23\end{array}$ & 4.760 \\
\hline 2 & $\begin{array}{l}\mathrm{T}_{2} \text { - Glyphosate 50gm/ha alone after emergence of } \\
\text { Orobanche }\end{array}$ & 16.40 & 4.180 \\
\hline
\end{tabular}




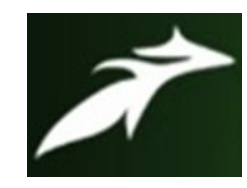

Ramakant Singh Sidar, International Journal of Advances in Agricultural Science and Technology, Vol.2 Issue.11, November- 2015, pg. 64-76

\begin{tabular}{|c|c|c|c|}
\hline 3 & $\mathrm{~T}_{3}$ - Trifluralin @ 1.5kg/ha PPI & 17.38 & 4.586 \\
\hline 4 & $\begin{array}{l}\mathrm{T}_{4-} \text { - Glyphosate } 25 \mathrm{gm} / \text { ha alone with } 1 \% \text { solution } \\
\mathrm{NH} 4 \mathrm{SO} 4 \text { at } 40 \mathrm{DAS}\end{array}$ & 16.73 & 4.296 \\
\hline 5 & $\begin{array}{l}\mathrm{T}_{5} \text { - Neem cake at } 200 \mathrm{~kg} / \mathrm{ha} \text { in furrow and } \\
\text { Pendimethalin at } 0.5 \mathrm{~kg} / \mathrm{ha}(\mathrm{PE}) \text { followed by } 1 \text { hoeing } \\
\text { at } 40 \mathrm{DAS}\end{array}$ & 18.37 & 4.523 \\
\hline 6 & $\begin{array}{l}\mathrm{T}_{6} \text { - Neem cake at } 200 \mathrm{~kg} / \mathrm{ha} \text { in furrow followed by } \\
\text { Imazethapyr } 30 \mathrm{gm} / \mathrm{ha} \text { at } 20 \mathrm{DAS}\end{array}$ & 16.38 & 3.910 \\
\hline 7 & $\mathrm{~T}_{7}$ - Trifluralin@1.5kg/ha +Neem oil 1\% PPI & 18.96 & 4.600 \\
\hline 8 & $\begin{array}{l}T_{8} \text { - Soybean oil } 2 \text { drops / shoot after emergence of } \\
\text { Orobanche }\end{array}$ & 15.19 & 4.016 \\
\hline 9 & $\begin{array}{l}\mathrm{T}_{9^{-}} \text {Application of } 25 \% \text { extra dose of phosphorus } \\
\text { and phosphorus solubilizing bacteria }\end{array}$ & S14.65 & 3.956 \\
\hline 10 & $\begin{array}{l}\mathrm{T}_{10^{-}} \text {- Trichoderma viride } 2.5 \mathrm{~kg} / \mathrm{ha} \text { as basal } \\
\text { application }\end{array}$ & 15.50 & 4.056 \\
\hline 11 & $\mathrm{~T}_{11}$ - Farmers practice-1 hoeing at 40DAS & 16.16 & 4.100 \\
\hline \multirow[t]{3}{*}{12} & $\mathrm{~T}_{12^{-}}$Weedy check & 13.99 & 3.820 \\
\hline & S.E.m \pm & $\mathbf{0 . 3 3}$ & 0.068 \\
\hline & C.D. at 5\% & 0.97 & 0.202 \\
\hline
\end{tabular}

